\title{
Original paper \\ Mineralogy and petrogenesis of pegmatites in the Spruce Pine District, North Carolina, USA
}

\author{
Samuel E. SWANSON*, William B. VEAL \\ Department of Geology, University of Georgia, Athens, Georgia 30602, United States of America; sswanson@uga.edu \\ ${ }^{*}$ Corresponding author
}

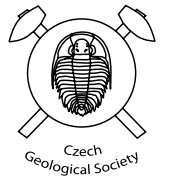

Granitic rocks (mainly granodiorites) of the Spruce Pine Plutonic Suite occur as small plutons and numerous pegmatite bodies intruded into amphibolite-grade schists and gneisses of the Ashe Formation. Intrusion ages range from 377 to 404 Ma and are near the peak of amphibolite-facies metamorphism in the country rocks. The granodiorites have a mortar texture with coarse $(\sim 1 \mathrm{~cm})$ grains of feldspar, quartz and muscovite enclosed in a finer grained matrix of the same phases. Large $(10-30 \mathrm{~cm})$ crystals of perthitic K-feldspar and plagioclase occur in the granodiorite. Pegmatites occur within the granodiorite and as isolated intrusions within the country rocks. Contacts between pegmatites and host granodiorites range from sharp, cross-cutting to completely gradational. Some of the plutons contain up to $50 \%$ pegmatite. Pegmatite mineralogy is similar to the granodiorites; major amounts of feldspars and quartz, accessory amounts of muscovite, garnet, and epidote. Secondary minerals, formed by subsolidus recrystallization, include epidote, muscovite, quartz, and grossular garnet. A few of the pegmatites are more fractionated and contain tourmaline and beryl. Compositions of feldspars, muscovite, and garnet show some regional variation, but are generally similar for pegmatites and associated granodiorite. About half of the pegmatites are unzoned. Zoning in the pegmatites is simple with a quartz core, an intermediate zone of graphic granite, plagioclase and muscovite and an outer finer grained zone that locally shows mineral layering parallel to the contact. The abundance of pegmatitic textures relative to granitoid textures in the Spruce Pine Plutonic Suite is related to the depth of crystallization. Spruce Pine granitoids crystallized at depths of 20-30 km (0.7 to $1.1 \mathrm{GPa}$ ) based on feldspar thermobarometry and experimentally determined melting relations. Skeletal crystals of quartz and feldspar along with plumose muscovite clusters are common in the Spruce Pine pegmatites. Water content of magmas at such high pressures can be high. The subtle transition from granitic to pegmatitic texture so common at Spruce Pine (and in other deep-seated systems) was probably related to the development of zones of water-enriched magma and delayed nucleation in the hydrous melts. Deformation (evidenced by mortar texture) of the Spruce Pine Plutonic Suite was related to later regional deformation.

Keywords: Spruce Pine, pegmatites, mineralogy, North Carolina

Received: 16 October 2009; accepted: 1 April 2010; handling editor: P. Nabelek

\section{Introduction}

Pegmatites of the Spruce Pine Mining District in western North Carolina have a long history of providing various minerals to mankind. Native Americans mined mica from the Spruce Pine pegmatites over 2000 years ago (Margolin 2000). Large sheets of muscovite and figures cut from muscovite are a common artifact in the mounds of the Mississippian Culture (Townsend and Sharp 2004). Modern mining of mica began in the 1860's (Olson 1944) with the production of large mica sheets initially for use as stove windows; later the mica was used as an electrical insulator. Ground mica continues to be produced from Spruce Pine today. Pegmatitic sources of feldspar and mica were the early targets of the miners because of their coarse grain size. The coarse-grained nature of feldspar at Spruce Pine facilitated hand sorting and feldspar production started in the early 1900's. Separation of feldspar and other minerals by flotation methods started in the Spruce Pine District in 1949 (Glover 2006) and continues to the present. Spruce Pine is a major supplier of feldspar in North America. Quartz, a major phase in Spruce Pine granitoid rocks, was discarded for years from the flotation plants as a waste product. Sand traps at the Augusta National golf course (Augusta, GA, USA) were filled with waste quartz sand from Spruce Pine. Mineral processors at Spruce Pine currently produce ultra high purity quartz for use in the electronics industry and in the production of high purity quartz glass. Quartz is a major product of the Spruce Pine District.

Spruce Pine pegmatites also hold a special place in the development of our understanding of pegmatite petrogenesis. During World War II, pegmatites at Spruce Pine were mapped as part of a U.S. program to identify domestic sources of quartz and mica to support the war effort. The U.S. Geological Survey (USGS) was in charge of the mapping program. Maps of various Spruce Pine pegmatites, dating from this era, are reproduced in numerous publications (e.g. Olson 1944; Cameron et al. 1949; Parker 1952; Jahns 1955; Brobst 1962; Le- 
sure 1968). Richard Jahns, a USGS geologist mapping Spruce Pine pegmatites during World War II, collected a bulk sample (about 500 tons) of a pegmatite from Chalk Mountain in the Spruce Pine District during his studies. The sample was crushed and sub-sampled. A number of experimental studies utilized this Spruce Pine sample (Jahns and Burnham 1957, 1958, 1969; Burnham and Jahns 1958, 1962; Burnham 1967; Vaughan 1963; Fenn 1986; Swanson and Fenn 1986).

The purpose of this study is to determine the relationship between the Spruce Pine granodiorites and the associated pegmatites. Despite a long mining history and a rich legacy of geologic information, relatively little is known about the Spruce Pine pegmatites (London 2008). This prompted London (2008) to devote several pages of basic description of Spruce Pine pegmatites in his recent tome on pegmatites. Spruce Pine pegmatites are mica pegmatites (Černý 1991) and relatively little is known about this type of pegmatite. This study adds to the general understanding of crystallization processes in mica pegmatites, and specifically to crystallization of Spruce Pine magmas.

\section{Geological background}

Granitic rocks of the Spruce Pine Plutonic Suite intrude schists and gneisses of the Ashe Formation in the Blue Ridge of the Appalachian Mountains in western North Carolina. The granitic rocks and their enclosing country rocks are part of the Spruce Pine thrust block, the structurally highest thrust sheet in the northern part of the Blue Ridge Belt of western North Carolina (Butler 1973; Stewart et al. 1997). Rocks of the Spruce Pine thrust block are part of the Tugaloo Terrane of Hatcher et al (2005, 2007), an exotic terrane composed of metasediments, interlayered amphibolite, small bodies of ultramafic rock and a few mafic-ultramafic complexes accreted to North America during the Taconic Orogeny. Schists and gneisses preserve a polyphase metamorphic history (Fig. 1) in mineral assemblages and structures (Butler 1973, 1991; Abbott and Raymond 1984; Adams et al. 1995). Peak metamorphism was assumed to be middle to upper amphibolite facies (Butler 1973; Abbott and Raymond 1984), but detailed mapping in the Spruce Pine thrust sheet revealed an earlier eclogite-facies metamorphic assemblage locally preserved near the base of the thrust sheet (Adams et al. 1995; Adams and Trupe 1997).

Ages of minerals in the schists and gneisses of the Spruce Pine area record multiple ages related to the closure temperature of different isotopic systems (Goldberg and Dallmeyer 1997). The oldest ages, recorded in amphibolite-facies hornblende and garnet by $\mathrm{K}-\mathrm{Ar}$ and $\mathrm{Sm}-\mathrm{Nd}$ isotopic systems, are between 450 and 470
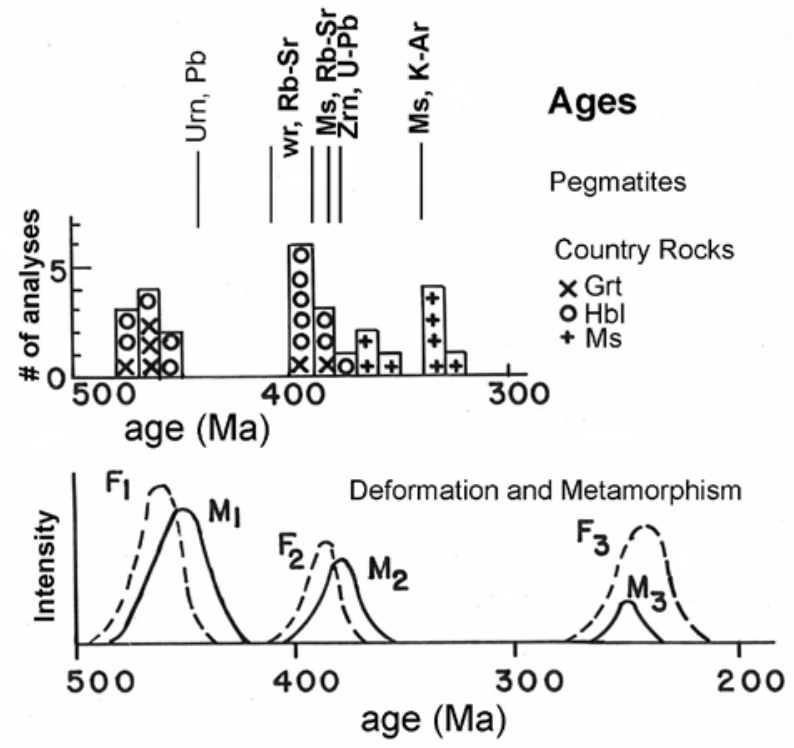

Fig. 1. Geochronology of the Spruce Pine area. The histogram is based on work by Goldberg and Dallmeyer (1997) on amphibolite, mica schist and gneiss; the country rocks for the Spruce Pine Plutonic Suite. Garnet ages are by $\mathrm{Sm}-\mathrm{Nd}$, hornblende ages are by $\mathrm{Rb}-\mathrm{Sr}$ and $\mathrm{Ar}-\mathrm{Ar}$, muscovite dates are by Ar-Ar. Ages of the Spruce Pine pegmatites are shown over the top of the histogram and include $\mathrm{U}-\mathrm{Pb}$ ages on uraninite (Aldrich et al. 1958) and zircon (Johnson et al. 2001), Rb-Sr wholerock isochrons on pegmatites (Kish 1983, 1989), and K-Ar dates on muscovite as compiled by Lesure (1968). Below the histogram is the model for deformation $\left(\mathrm{F}_{1}, \mathrm{~F}_{2}, \mathrm{~F}_{3}\right)$ and metamorphism $\left(\mathrm{M}_{1}, \mathrm{M}_{2}, \mathrm{M}_{3}\right)$ in the Spruce Pine area as proposed by Butler (1973).

Ma (Fig. 1). Another cluster of hornblende and garnet ages occurs at 370-390 Ma. Muscovite argon release spectra give ages of 325-335 Ma, while $\mathrm{Rb}-\mathrm{Sr}$ muscovite ages are somewhat older (350-360 Ma, Goldberg and Dallmeyer 1997). Age of the earlier eclogite-facies metamorphic event was given as 459 Ma (Miller et al. 2000). A later amphibolite-facies overprint on the eclogite facies assemblages was dated by a titanite age of $394 \mathrm{Ma}$ (Miller et al., 2000). Thus at the time of intrusion of the Spruce Pine granodiorite magmas, the country rocks were at amphibolite grade. Estimates of the amphibolite-facies metamorphic conditions are $0.7-0.9 \mathrm{GPa}, 640-700{ }^{\circ} \mathrm{C}$ based on garnet cores and inclusions in pelitic rocks and 0.8 to $1.0 \mathrm{GPa}, 675-705{ }^{\circ} \mathrm{C}$ for amphibolites (Goldberg and Dallmeyer 1997).

The first age determination on the Spruce Pine granitic rocks was done on uraninite from a pegmatite and yielded an age of $440 \mathrm{Ma}$ (Aldrich et al. 1958; Fig. 1). Warner et al. (2008) showed complex intergrowths of uranium oxide minerals in the Spruce Pine pegmatites and this complexity makes the early $\mathrm{U}-\mathrm{Pb}$ dates on uraninite questionable. Whole rock $\mathrm{Rb}-\mathrm{Sr}$ ages for two Spruce Pine pegmatites are 404 and $392 \mathrm{Ma}$ (Kish 1983, 1989) while Johnson et al. (2001) reported a U-Pb zircon age of $377 \mathrm{Ma}$ for a Spruce Pine Pluton. Spruce Pine magmas 

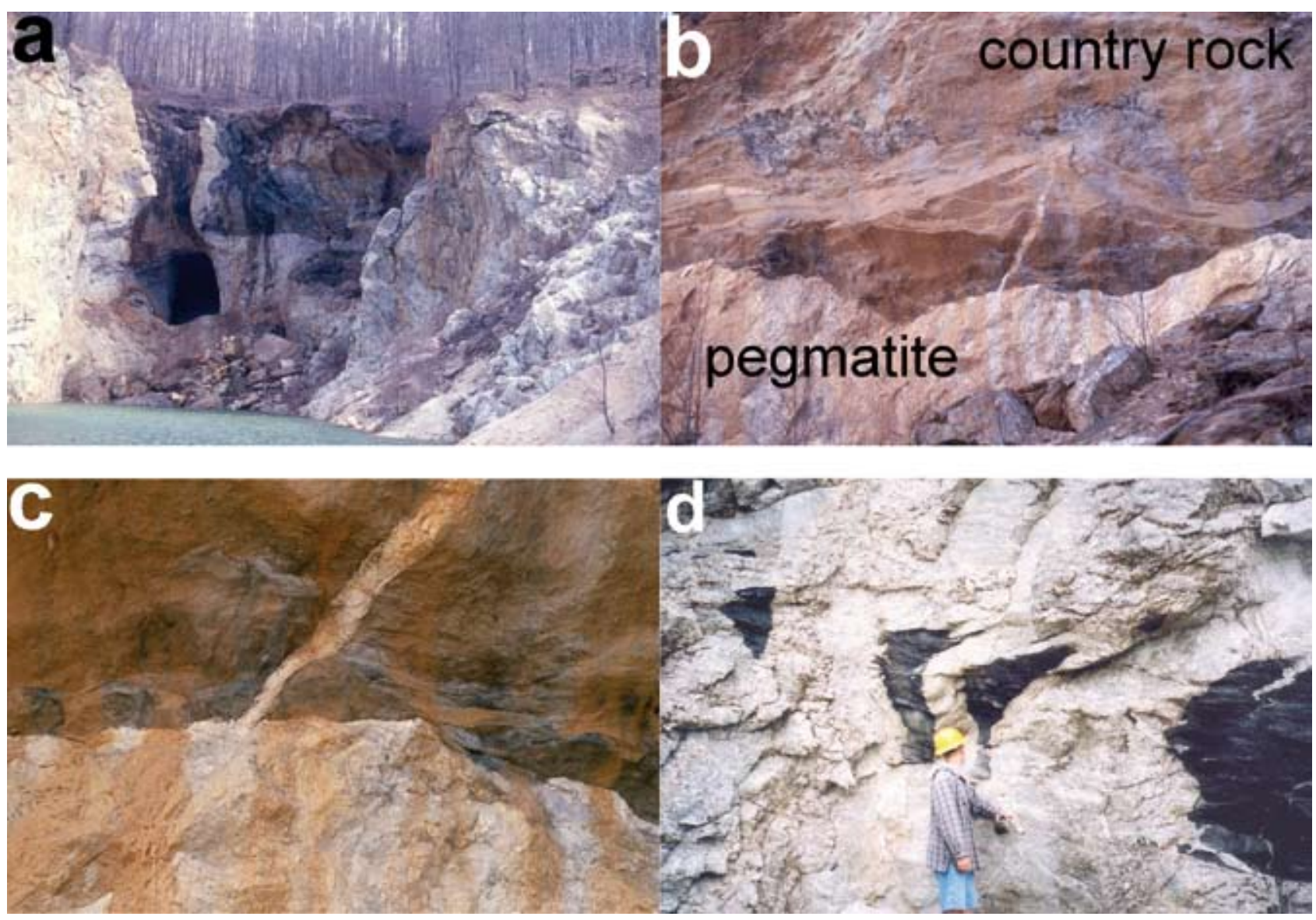

Fig. 2 Contact relations of Spruce Pine pegmatite dikes and sills. a - Contact of the McKinney Mine stock (white rock) intruding dark schists of the Ashe Formation. Horizontal contact is parallel to the regional foliation, cut by the vertical dike. $\mathbf{b}-$ Contact of the McKinney Mine intrusion (white rock) is generally conformable to the foliation of the schists of the Ashe Formation, small dike cuts the schist foliation. Width of crosscutting dike is $0.3 \mathrm{~m}$. $\mathbf{c}$-Close-up view of $\mathbf{b}$. $\mathbf{d}$ - Disrupted schist xenolith (dark) broken apart by dike intrusions in the Minpro Pluton, author Veal for scale.

were intruded near the end of the peak middle to upper amphibolite facies metamorphism (370-390 Ma, Fig. 1, Goldberg and Dallmeyer 1997).

Spruce Pine granitic rocks are commonly intruded parallel to the regional foliation forming sills. Locally Spruce Pine dikes and plutons cross cut early folds and the regional foliation of the country rocks (Butler 1973) (Fig. 2). Xenoliths of schist and gneiss within the granitoid rocks are common, especially along the margins of the plutons. The spotty pattern shown in the plutons on Fig. 3 (called "digital scribble" by one reviewer) is a representation of the country rock xenoliths. Contacts between the granitic rocks and the country rocks are sharp and typically marked by a zone of injection of granitic magma along metamorphic rocks foliation. Alignment of mica grains, streaks of feldspar and quartz, and parallel linear arrangements of garnet or mica define a foliation along the margins of some intrusions, especially in the plutons.

\subsection{Spruce Pine granitoid rocks}

Rocks of the Spruce Pine Plutonic Suite are peraluminous, S-type granitic rocks. The intrusions are composed of coarse-grained, light-colored muscovite granodiorite with more plagioclase than K-feldspar. Pegmatitic and coarse-grained granitoid rocks have very similar chemical and mineralogic compositions suggesting a genetic link (Olson 1944). Older literature refers to these rocks as alaskite because of the low mafic mineral content. Common accessory minerals include garnet and epidote and, less commonly, biotite. Less common are rare Uoxide minerals (Warner et al. 2008) and apatite. A few intrusions are characterized by accessory amounts of beryl and tourmaline (Tappen and Smith 2003). At least one intrusion contains spodumene and more exotic REE minerals (Wise and Brown 2009).

The coarse-grained nature of the granodiorite together with the occurrence of isolated, large K-feldspar phe- 


\section{Spruce Pine Mining District}

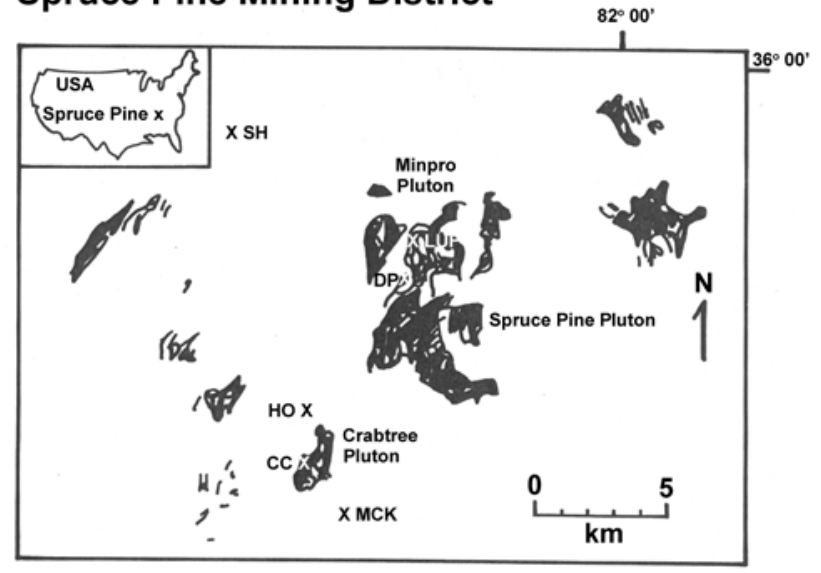

Fig. 3 Map of plutons in the Spruce Pine Plutonic Suite. Town of Spruce Pine is in the Spruce Pine Pluton. Minpro Pluton hosts the Deep Park pegmatites (DP) and the LUF pegmatite studied by Swanson (2008). Other studied pegmatites are McKinney Mine (MCK), Hoot Owl Mine (HO), Sinkhole (SH), and Crabtree Creek (CC).

nocrysts within the granodiorite leads to some confusion over the use of the term pegmatite. Some people refer to all of the Spruce Pine granitoid rocks as pegmatite. Jahns (1955) applied the term pegmatite to rocks "that are at least in part very coarse grained ... (with) extreme textural variations, especially in grain size". London (2008) redefined pegmatite to include rocks with variable size or crystals with skeletal, graphic, or crystal growth oriented perpendicular to the pegmatite margin. In this paper we use the term pegmatite to refer to a rock composed of very coarse-grained crystals of feldspar, muscovite and quartz, usually in a finer grained matrix that includes the same phases with some evidence of heterogeneous nucleation and/or unidirectional solidification textures (Shannon et al. 1982).

Most of the Spruce Pine granitic rocks show some evidence of post-magmatic recrystallization related to deformation (Lesure 1968). Feldspar and mica grains have bent and broken twin and cleavage planes. Large quartz grains have undulose extinction. Broken and bent crystals of feldspar and granulated quartz are commonly included in a matrix of fine-grained feldspar, quartz, and muscovite. Muscovite flakes are often bent and wrap around grains of feldspar or garnet. Fine-grained skeletal overgrowths are common as terminations on muscovite grains. Shear zones within the pegmatite and granite bodies are irregular surfaces covered with finegrained quartz, muscovite, and epidote. The deformation is clearly post-magmatic and may be related to a late-stage deformation noted in the schists and gneisses that post-dated the peak metamorphic event (Fig. 1; Butler 1973).

\subsection{Pegmatites}

Hundreds of bodies of pegmatite occur within the Spruce Pine Mining District. Host rocks for the pegmatites include the granodiorites of the Spruce Pine Plutonic Suite and the schists and gneisses of the Ashe Formation. Pegmatites within the schists form tabular to lenticular sills conformable to the foliation. Many of the larger pegmatites mapped in the country rock are actually intrusions of granodiorite with abundant pegmatite zones. Pegmatites hosted by granodiorite range from irregular bodies to tabular dikes with sharp contacts. Contacts between pegmatite and granodiorite vary from gradational to sharp. A gradual coarsening of grain size and an increase in the amount of quartz-K-feldspar intergrowths mark the transition from granitoid to pegmatite (Fig. 4). Pegmatites vary in size from a few large crystals $(<1 \mathrm{~m}$ long) to large (hundreds of meters long, tens of meters wide; Olson 1944).

Approximately half of the Spruce Pine pegmatites are uniform and lack internal zoning (Parker 1952). When present, zoning consists of outer zones concentric upon a core. Approximately $25 \%$ of the zoned Spruce Pine pegmatites have a thin, fine-grained border zone and a coarser grained wall zone, both consisting of plagioclase, $\mathrm{K}$-feldspar and quartz. A core of quartz, with or without coarse-grained $\mathrm{K}$-feldspar, is surrounded by a medium to coarse-grained and an outer fine-grained zone. The two outer zones are composed of quartz, K-feldspar, and plagioclase (Parker 1952). The other quarter of the Spruce Pine pegmatites contains more than three zones based on a subdivision of border and wall zones. Cameron et al. (1949) gave a comprehensive listing of zones in Spruce

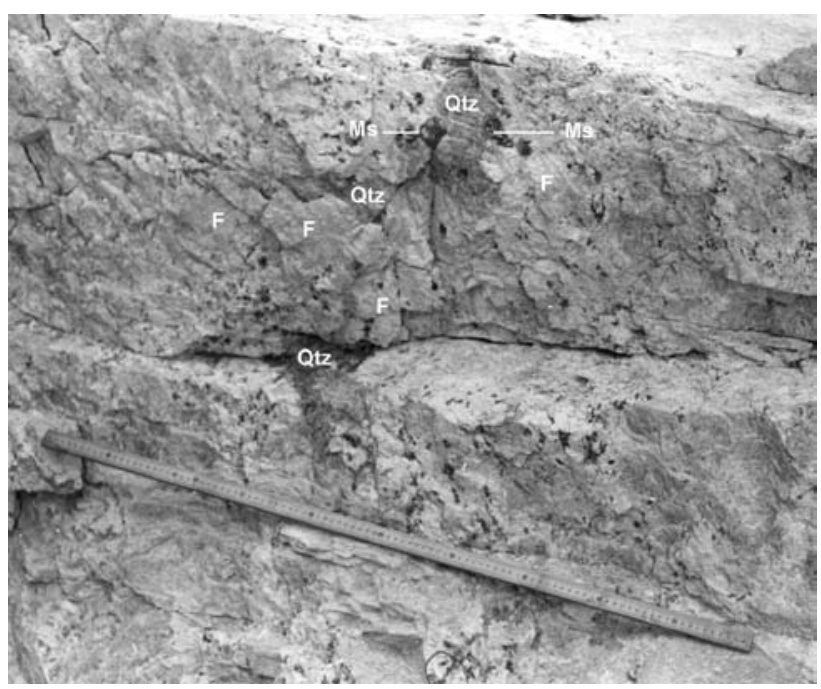

Fig. 4 Gradational contacts between host granodiorite in the Minpro Pluton pegmatite with quartz core (Qtz) and outer zone of coarse feldspar (F) and muscovite (Ms). Note meter stick for scale. 
Pine pegmatites. Major minerals in the outer (border and wall) pegmatite zones are quartz, plagioclase, K-feldspar, and muscovite. Pegmatite cores contain massive quartz \pm very coarse-grained K-feldspar (Fig. 5). Graphic granite and skeletal crystals of quartz are found in the outer zones of Spruce Pine pegmatites (Maurice 1940). Unidirectional solidification textures (USTs), represented by plumose muscovite and inward-pointing feldspar crystals, also are found in the outer pegmatite zones. Substrates for USTs are sometimes decorated with garnet crystals, forming a structure similar to line rock.

Fine-grained (aplitic) equigranular granitic rock is a rare part of the Spruce Pine Plutonic Suite. Dikes of aplitic granodiorite intrude pegmatitic rocks and form irregular elongate masses that parallel some of the pegmatite dikes. Mineral layering, so called line rock, occurs in some of the aplitic dikes.

Textures in Spruce Pine pegmatites are dominated by magmatic features. The large skeletal and dendritic crystal forms pictured in Maurice (1940) and Raymond (1995, pp. 196, 225, 226, 232) and discussed by Swanson (1978a, b), and Fenn (1986) are all features of magmatic crystallization (London 2008). Pegmatites also contain post-magmatic features, such as the feldspar exsolution, deformation in the feldspar and muscovite, and a fine-grained mortar texture between large grains of feldspar, quartz, and muscovite related to post-magmatic recrystallization.

\subsection{Spruce Pine compositions in experiments}

Jahns collected several bulk samples of pegmatites, including Spruce Pine pegmatites, during his tenure with the USGS during World War II. Large samples were assembled from cross-sections of the pegmatites made during the active mining operations. After the war, Jahns joined Burnham at Penn State University and one of the Spruce Pine samples (JB5) was used in experimental studies. The JB5 sample is from a pegmatite in the Chalk Mountain Pluton (Fig. 3). Jahns and Burnham $(1957,1958)$ reported on the melting relations of the Spruce Pine (and other) compositions. Burnham and Jahns (1962) used JB5 in their study of the solubility of water in silicate melts, but they only showed results for a bulk composition from the Harding pegmatite. A Masters graduate student at Penn State University performed melting experiments on the JB5 Spruce Pine composition (Vaughan 1963). Experiments on fractionation of components into a vapor phase in equilibrium with JB5 at various pressures were reported by Burnham (1967). Based on experiments with the pegmatite compositions, Jahns and Burnham (1969) presented their model for the formation of pegmatites. Fenn (1986) and Swanson and Fenn (1986) used JB5, and other compositions, in studies of the development of graphic granite and the crystalliza- tion of skeletal quartz. A comparison of experimentally determined phase equilibria for JB5 and calculated phase equilibria from a thermodynamic model for silicate melts was presented by Burnham and Nekvasil (1986).

\subsection{Recent studies of Spruce Pine pegmatites}

Three Masters theses (Wood 1995; Tappen 1998; Veal 2004) focused on pegmatites in the Spruce Pine area. Wood (1995) analyzed minerals in one sample from a number of pegmatites in the Spruce Pine area and reported on the regional compositional variation of muscovite, feldspar, and garnet. Tappen (1998) studied the occurrence or green beryl (emerald) in a tourmaline and berylbearing Spruce Pine pegmatite and later published these results (Tappen and Smith 2003). Veal (2004) compared the mineralogy of pegmatites to associated granodiorites and his results are incorporated into this paper.

Most recently attention to Spruce Pine pegmatites was drawn by mining activities and regional field trips. Glover (2006) and Swanson and Veal (2006) presented overviews of the recent mining of Spruce Pine rocks and the importance of textural variation in the Spruce Pine granitoids. London (2008) included Spruce Pine in his discussion of deeply emplaced pegmatites and called attention to the occurrence of large phenocrysts of K-feldspar within the Spruce Pine granodiorites that caused some confusion. Warner et al. (2008) reported on the complex mineralogy of U-Th minerals in the Spruce Pine pegmatites. A small pegmatite (LUF) in the Minpro Pluton (Fig. 3) of the Spruce Pine Plutonic Suite provided a model for the crystallization of Spruce Pine pegmatites (Swanson 2008). A rare Li, REE-enriched Spruce Pine pegmatite was attributed to extreme fractionation from granodiorite magma (Wise and Brown 2009).

\section{Methods}

\subsection{Sampling}

Samples were selected from mines in the Crabtree Creek and Minpro plutons within the Spruce Pine mining district (Fig. 3). Samples from mines in isolated intrusions at McKinney, Hoot Owl, Sink Hole, and Deer Park were also selected for study. Samples were collected from walls of the existing mine at all locations except Sink Hole and Deer Park. The mine walls are no longer accessible at Sink Hole and Deer Park where coarse-grained samples were selected from the mine dumps. Access to the current active mining operations at Spruce Pine is very restricted. Samples used in this study are from abandoned pegmatite mines and from the first authors' collections made over 35 years of Spruce Pine studies. 


\subsubsection{Crabtree Creek Pluton}

Outcrops studied in the Crabtree Creek Pluton (Fig. 3) contain pegmatites hosted in granodiorite (Fig. 5). The granodiorite is medium- to coarse-grained (1 to $20 \mathrm{~mm}$ ) and contains areas of dendritic biotite. Gradual coarsening of the grain size in the granodiorite over $\sim 10 \mathrm{~cm}$ marks the transition from granodiorite to a tabular pegmatite zone c. $30 \mathrm{~cm}$ wide. The zoned pegmatite contains an irregular core of smoky quartz. Coarse-grained crystals of perthitic and graphic K-feldspar, muscovite and plagioclase make up the zone adjacent to the core.

A finer grained outer zone of plagioclase, K-feldspar, quartz, and garnet account for the rest of the pegmatite. Large crystals of green muscovite up to $8 \mathrm{~cm}$ in diameter and $4 \mathrm{~cm}$ thick are concentrated along the margin of the quartz core and occur as isolated crystals therein.
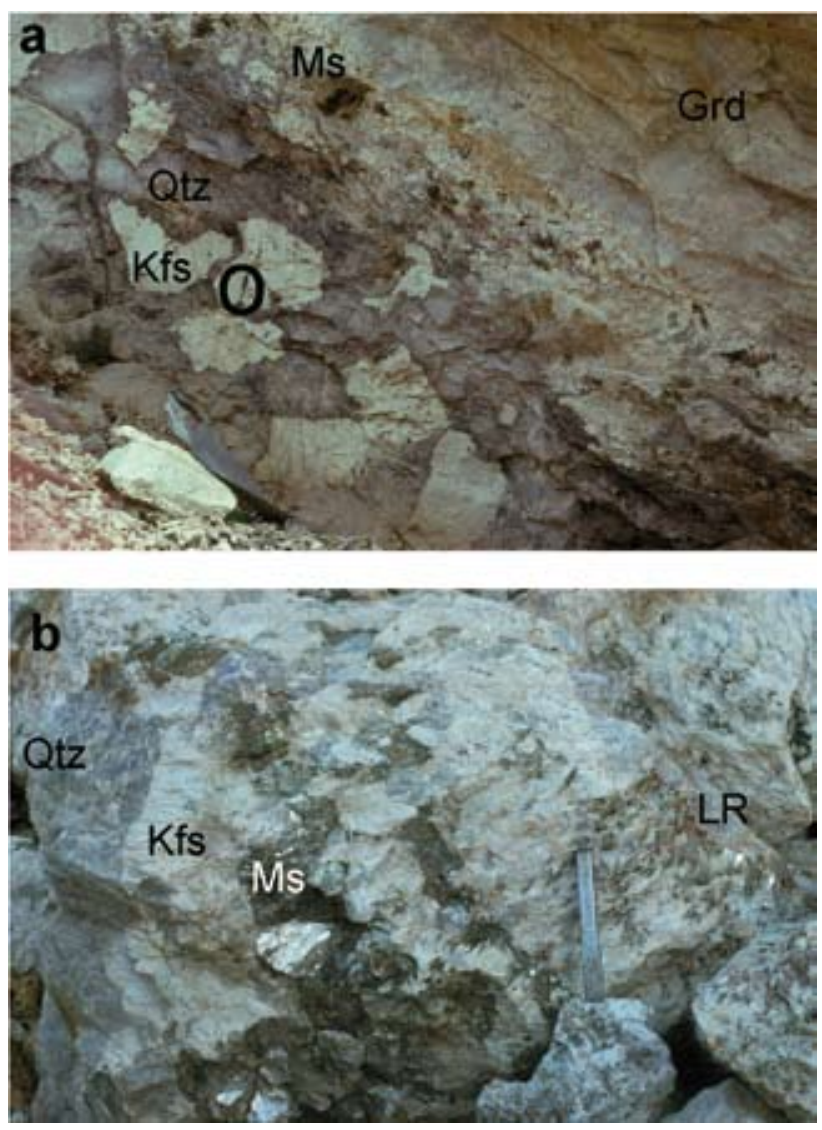

Fig. 5a - Large zoned pegmatite. Core of large crystals of K-feldspar (Kfs; note circled $45 \mathrm{~cm}$ long hammer) in smoky quartz (Qtz), hanging wall composed of quartz + feldspar + muscovite (Ms), hosted in granodiorite (Grd) in Minpro Pluton. $\mathbf{b}$ - Small pegmatite in the McKinney Mine intrusion. Quartz core (Qtz) and adjacent K-feldspar (Kfs), UST of plumose muscovite (Ms) pointing toward the core. LR - line rock. Chisel is $15 \mathrm{~cm}$ long.

\subsubsection{Minpro Pluton}

The largest active mines in the Spruce Pine District are in the Minpro Pluton, located to the north and west of the town of Spruce Pine (Fig. 3). The Minpro Pluton is formed by numerous individual intrusions that coalesced together with local small screens of country rock caught along the intrusion contacts (Fig. 2d). Most of the Minpro Pluton is composed of medium- to coarse-grained garnetbearing granodiorite. Most of mica in the granodiorite is muscovite, but a trace of biotite is also found. The granodiorite hosts numerous pegmatites. Some of the pegmatites occur as the isolated, pod-like bodies with gradational contacts against the granodiorite (Fig. 4). Swanson (2008) reported on one of these pegmatites (LUF, Fig. 3) in the Spruce Pine Pluton. Other tabular pegmatite dikes with sharp contacts cut the granodiorite of the Spruce Pine Pluton. Some of these tabular pegmatites are large, over $30 \mathrm{~m}$ in thickness (Fig. 5a). Pegmatites are marked by a core of smoky quartz with isolated crystals of perthitic K-feldspar. Grain size of the pegmatites increases from the margin to the core. Very coarse-grained (several tens of centimeters) quartz, feldspar, and mica are found outboard of the core surrounded by a finer grained matrix of these same minerals plus garnet. Discontinuous layers of fine-grained garnet parallel the margins of some tabular pegmatites. Irregular dikes of fine-grained (aplitic) granodiorite parallel and cross-cut the tabular pegmatites. Samples from the Minpro Pluton include a suite of grab samples from the Deer Park mines, pegmatite and host granodiorite at LUF (Swanson 2008), and various granodiorites.

\subsubsection{McKinney, Hoot Owl, and Sinkhole mines}

Small, isolated intrusions of granodiorite in country rock have variable amount of pegmatite. At the McKinney Mine area (Fig. 3) several tabular pegmatites were mined for their coarse-grained feldspar and muscovite. Some of the pegmatites are zoned with a quartz $+\mathrm{K}$-feldspar core. Coarse-grained muscovite (diameter up to $30 \mathrm{~cm}$ ) is also associated with the outer part of the zoned pegmatites. Unidirectional solidification textures (Fig. 5b) are associated with some wall-zone pegmatite. Shear zones along the margins of some pegmatites contain quartz and very fine-grained muscovite. Fracture-fillings of quartz (not to be confused with pegmatite) also occur at McKinney (Cameron et al. 1949). Samples represent pegmatite and host granodiorite.

The Hoot Owl Mine (Fig. 3) is another small intrusion into the mica schists and gneisses. Granodiorite at the Hoot Owl mine has very coarse grains of $\mathrm{K}$-feldspar in a coarse-grained granodiorite. Unzoned, tabular pegmatites 
composed of quartz-muscovite or quartz-muscovitefeldspar-garnet occur at the Hoot Owl. Fracture fillings of quartz cut the Hoot Owl granodiorite. Samples of pegmatite and host granodiorite are included in this study.

Native Americans were the first to mine the coarsegrained muscovite at the Sinkhole Mine (Fig. 3) (Margolin 2000). The mine was later developed for feldspar and muscovite starting in the $1800^{\circ} \mathrm{s}$ and is now only represented by extensive dumps and filled shafts. Samples of coarse-grained feldspar, muscovite, biotite, garnet and fine-medium-grained garnet were collected from materials on the dumps.

\subsection{Electron microprobe analyses}

Electron microprobe analyses of a few feldspars from the LUF pegmatite were done by W. C. Luth at Sandia National Laboratory using an ARL electron microprobe. Other microprobe analyses were carried out in the microprobe laboratory in the Department of Geology at the University of Georgia using a JEOL-8600 Superprobe. An accelerating voltage of $15 \mathrm{kV}$ and a sample current of $5 \mathrm{nA}$ were used in the analyses. Beam diameter varied with mineral phase analyzed: $10 \mu \mathrm{m}$ for mica and feldspar and $2 \mu \mathrm{m}$ for garnet. Synthetic and natural minerals were used for standards. Data were reduced using Phi-Rho-Z techniques.

\section{Mineralogy}

Plagioclase, K-feldspar, quartz, and mica grains are variable in size, ranging from less than a $\mathrm{mm}$ to several tens of $\mathrm{cm}$ in rocks of the Spruce Pine Plutonic Suite. The margins of some of the larger feldspar and quartz grains are surrounded by a narrow zone of fine-grained recrystallized quartz, feldspar, and muscovite that forms a mortar structure. Bent and broken feldspar twin planes and undulose extinction in quartz also support post-magmatic deformation in the granodiorites and pegmatite. Subhedral to euhedral garnet crystals are sometimes enclosed in muscovite flakes.

\subsection{Feldspars}

Plagioclase is more abundant than K-feldspar in the Spruce Pine granodiorites and pegmatites. Maurice (1940) noted that little K-feldspar is found in pegmatites with calcic oligoclase. Modal analysis of a small pegmatite (LUF, Fig. 3) in the Minpro Pluton yielded an estimate of $34 \% \mathrm{~K}$-feldspar and $58 \%$ plagioclase (Swanson 2008). Grain size of plagioclase in the granodiorite ranges from 0.1 to $300 \mathrm{~mm}$, while plagioclase in pegmatites reaches over $500 \mathrm{~mm}$. Albite twinning is well developed in the plagioclase and is often deformed. The plagioclase is antiperthitic with stringers of K-feldspar. Much of the pegmatitic plagioclase contains graphic quartz intergrowths.

Most plagioclase grains have cores composed of sodic oligoclase (Tab. 1) and show a few mole percent albite of normal zoning to the rim. Albitic rims (Tab. 1) are found on cores of sodic oligoclase at Hoot Owl, Crabtree and McKinney (Fig. 3). Compositions of the albite rims are similar to the albite exsolution in coexisting perthitic Kfeldspar. This reflects formation of both albite rims and exsolution lamellae at subsolidus conditions. Plagioclase in the fine-grained mortar texture is albite (Tab. 1).

$\mathrm{K}$-feldspar forms large (over $1 \mathrm{~m}$ ) crystals in the pegmatites and granodiorites; it is typically perthitic. Intergrowths with quartz forming a graphic texture are common. Most of the $\mathrm{K}$-feldspar is perthitic with albite exsolutions in a $\mathrm{K}$-feldspar host. Compositions of the $\mathrm{K}$-feldspar show little variation between pegmatite and granodiorite (Tab. 1). Fine-grained K-feldspar in the mortar texture is nearly the pure end member (Or 98, Tab. 1). X-ray analysis of the K-feldspar following the method of Wright (1968) showed the structural state in the LUF pegmatite (Fig. 3) to be near maximum microcline (Swanson 2008).

Feldspar compositions generally show similar patterns of variation between pegmatite and host granodiorite (Tab. 1). Maurice (1940) noted that the more sodic plagioclase occurs in the area south of the town of Spruce Pine (Fig. 3) and the sodic plagioclase at McKinney is consistent with that observation.

Modal proportions of host-exsolved feldspar phases, combined with composition of the feldspars (Tab. 2), yielded pre-exsolution estimates of magmatic feldspar compositions for a small pegmatite in the Minpro Pluton (Swanson 2008). Estimates of pre-exsolution K-feldspar compositions range from $\mathrm{Ab}_{9}$ to $\mathrm{Ab}_{16}$. Estimates of preexsolution plagioclase compositions are uniform at $\mathrm{Ab}_{91}$ (Swanson 2008).

\subsection{Quartz}

Quartz is a major mineral in the Spruce Pine granitoids, generally ranging from 25 to 35 percent (Maurice 1940). Quartz is present as medium- to very coarse-grained primary crystals and as fine-grained, recrystallized grains in the mortar texture. Most of the larger quartz grains are anhedral and show undulose extinction.

\subsection{Muscovite}

Muscovite is a widespread, minor component found in all the pegmatites and granodiorites of the Spruce Pine Plutonic Suite. Muscovite forms green to light-brown grains ranging from 0.1 to $300 \mathrm{~mm}$, most of the mica is 
Tab. 1 Summary of feldspar compositions in pegmatite and host granodiorite, Hoot Owl Mine

\begin{tabular}{|c|c|c|c|c|c|c|c|c|c|}
\hline \multirow{4}{*}{ texture of analyzed grain } & \multicolumn{6}{|c|}{ Host granodiorite } & & & \\
\hline & \multicolumn{6}{|c|}{ Plagioclase (mole \%) } & \multirow{2}{*}{\multicolumn{3}{|c|}{$\begin{array}{c}\text { K-feldspar (mole \%) } \\
\text { core }\end{array}$}} \\
\hline & \multicolumn{3}{|c|}{ core } & \multicolumn{3}{|c|}{ rim } & & & \\
\hline & $\mathrm{Ab}$ & An & Or & $\mathrm{Ab}$ & An & Or & $\mathrm{Ab}$ & An & Or \\
\hline large & 90.6 & 8.0 & 1.4 & 98.4 & 0.3 & 1.3 & 3.8 & 0.0 & 96.2 \\
\hline large & 89.0 & 9.5 & 1.5 & 97.4 & 1.1 & 1.5 & - & - & - \\
\hline large & 86.3 & 11.3 & 2.4 & 87.3 & 10.8 & 1.9 & - & - & - \\
\hline large & 85.1 & 13.2 & 1.7 & nd & nd & nd & - & - & - \\
\hline $\bar{x}$ & 87.8 & 10.5 & 1.8 & 94.4 & 4.1 & 1.6 & & & \\
\hline s.d. & 2.5 & 2.2 & 0.5 & 6.1 & 5.8 & 0.3 & & & \\
\hline small, mortar & 98.0 & 1.0 & 1.0 & 98.6 & 0.8 & 0.6 & 2.0 & 0.0 & 98.0 \\
\hline \multicolumn{10}{|c|}{ Pegmatite (all cores, mole \%) } \\
\hline very large & 87.0 & 12.2 & 0.7 & & & & 4.2 & 0.4 & 95.4 \\
\hline very large & 88.4 & 11.2 & 0.4 & & & & 3.2 & 0.0 & 96.8 \\
\hline very large & 83.9 & 14.4 & 1.7 & & & & 4.0 & 0.2 & 95.8 \\
\hline very large & 90.6 & 9.0 & 0.4 & & & & 3.7 & 0.0 & 96.3 \\
\hline $\bar{x}$ & 87.5 & 11.7 & 0.8 & & & & 3.8 & 0.2 & 96.2 \\
\hline s.d. & 2.8 & 2.2 & 0.6 & & & & 0.4 & 0.2 & 0.7 \\
\hline
\end{tabular}

$\bar{x}=$ mean

s.d. $=$ one standard deviation

Tab. 2 Modal and chemical data for coarse-grained feldspars in the LUF pegmatite (modified from Swanson 2008)

\begin{tabular}{|c|c|c|c|c|}
\hline \multirow[b]{2}{*}{ Host crystal } & \multicolumn{2}{|c|}{ Modal (volume \%) } & \multicolumn{2}{|c|}{ Mole (mole \% Ab) } \\
\hline & K-feldspar & Plagioclase & K-feldspar & Plagioclase \\
\hline \multicolumn{5}{|l|}{ Sample 2} \\
\hline K-feldspar & 98.0 & 1.3 & $7.1 \pm 1.3$ & $4.5 \pm 2.4$ \\
\hline Plagioclase & 2.0 & 98.7 & $98.1 \pm 1.3$ & $90.2 \pm 2.0$ \\
\hline $\mathrm{n}=\mathrm{pts}$ & $2517^{1}$ & $1538^{1}$ & $21 \mathrm{Kfs}, 17 \mathrm{Pl}$ & $9 \mathrm{Kfs}, 25 \mathrm{Pl}$ \\
\hline \multicolumn{5}{|l|}{ Sample 8} \\
\hline K-feldspar & 89.8 & 1.0 & $6.0 \pm 1.1$ & $4.6 \pm 0.9$ \\
\hline Plagioclase & 10.2 & 99.0 & $98.2 \pm 1.3$ & $90.2 \pm 0.9$ \\
\hline $\mathrm{n}=\mathrm{pts}$ & $4857^{1}$ & $2797^{1}$ & $21 \mathrm{Kfs}, 11 \mathrm{Pl}$ & $13 \mathrm{Kfs}, 10 \mathrm{Pl}$ \\
\hline \multicolumn{5}{|l|}{ Sample 10} \\
\hline K-feldspar & 89.1 & 3.4 & $6.0 \pm 1.1$ & $4.6 \pm 0.9$ \\
\hline Plagioclase & 10.9 & 96.6 & 98.2 & $90.7 \pm 1.3$ \\
\hline $\mathrm{n}=\mathrm{pts}$ & $4047^{1}$ & $3926^{1}$ & $21 \mathrm{Kfs}, 9 \mathrm{Pl}$ & $13 \mathrm{Kfs}, 21 \mathrm{Pl}$ \\
\hline \multicolumn{5}{|l|}{ Sample 16A } \\
\hline K-feldspar & 95.3 & 0 & $5.9 \pm 1.6$ & $91.3 \pm 1.1$ \\
\hline Plagioclase & 4.7 & 100 & $98.1 \pm 0.7$ & - \\
\hline $\mathrm{n}=\mathrm{pts}$ & $3764^{1}$ & 0 & $18 \mathrm{Kfs}, 9 \mathrm{Pl}$ & $10 \mathrm{Pl}$ \\
\hline
\end{tabular}

${ }^{1}$ point spacing $0.3 \mathrm{~mm}$

medium to very coarse-grained. Larger grains of subhedral to euhedral muscovite are referred to as "books". Largest muscovite grains are found in the pegmatites. In zoned pegmatites, the largest muscovite occurs in the zone adjacent to the quartz-K-feldspar core. Finer grained dendritic muscovite occurs as distinct grains and as overgrowths on larger, more euhedral muscovite crystals. Very fine-grained muscovite formed in the finegrained mortar texture between larger grains of feldspar and quartz. Grains of epidote, garnet, and biotite occur as flattened inclusions within the sheets of coarse-grained muscovite books (Lesure 1968).

The white mica in Spruce Pine granitoid rocks is referred to as muscovite, but it contains a significant 
Tab. 3 Composition of representative muscovite in pegmatite and granodiorite from Sink Hole (SH), Deer Park (DP), LUF, Hoot Owl (HO), Crabtree Creek (CC), and McKinney (MCK) (Fig. 1)

\begin{tabular}{|c|c|c|c|c|c|c|c|c|c|c|}
\hline \multirow{2}{*}{ wt. $\%$ oxide } & \multicolumn{6}{|c|}{ Pegmatite } & \multicolumn{4}{|c|}{ Granodiorite } \\
\hline & SH14.2 & DP3.1 & LUF1.7.1 & HO1-4 & $\mathrm{CC} 2-9$ & MCK3-1 & MP84-2 & HO1.5 & $\mathrm{CC} 2-8$ & MCK3-2 \\
\hline $\mathrm{SiO}_{2}$ & 46.42 & 46.02 & 45.45 & 47.61 & 47.11 & 46.02 & 46.34 & 47.10 & 47.36 & 46.31 \\
\hline $\mathrm{TiO}_{2}$ & 0.20 & 0.23 & 0.13 & 0.17 & 0.28 & 0.03 & 0.12 & 0.12 & 0.24 & 0.07 \\
\hline $\mathrm{Al}_{2} \mathrm{O}_{3}$ & 33.62 & 30.24 & 29.18 & 32.81 & 31.87 & 33.15 & 30.66 & 32.52 & 30.54 & 31.65 \\
\hline $\mathrm{FeO}_{\mathrm{t}}$ & 2.06 & 4.63 & 6.19 & 3.10 & 4.64 & 3.67 & 4.81 & 3.68 & 5.24 & 4.74 \\
\hline $\mathrm{MgO}$ & 0.72 & 1.20 & 1.05 & 0.86 & 0.92 & 0.27 & 1.37 & 0.86 & 1.56 & 0.45 \\
\hline $\mathrm{Na}_{2} \mathrm{O}$ & 0.56 & 0.42 & 0.40 & 0.35 & 0.35 & 0.15 & 0.48 & 0.52 & 0.28 & 0.42 \\
\hline $\mathrm{K}_{2} \mathrm{O}$ & 10.01 & 10.84 & 10.35 & 10.23 & 10.32 & 10.89 & 10.73 & 10.08 & 8.94 & 10.41 \\
\hline Total & 93.59 & 93.58 & 92.75 & 95.13 & 95.49 & 94.18 & 94.51 & 94.88 & 94.16 & 94.05 \\
\hline \multicolumn{11}{|c|}{ cations based on 22 oxygens } \\
\hline $\mathrm{Si}$ & 6.292 & 6.373 & 6.392 & 6.366 & 6.358 & 6.268 & 6.354 & 6.360 & 6.440 & 6.362 \\
\hline $\mathrm{Ti}$ & 0.010 & 0.023 & 0.014 & 0.017 & 0.029 & 0.003 & 0.013 & 0.012 & 0.024 & 0.007 \\
\hline $\mathrm{Al}$ & 5.371 & 4.931 & 4.835 & 5.172 & 5.070 & 5.322 & 4.954 & 5.178 & 4.896 & 5.124 \\
\hline $\mathrm{Fe}$ & 0.233 & 0.536 & 0.728 & 0.346 & 0.524 & 0.418 & 0.552 & 0.416 & 0.596 & 0.544 \\
\hline $\mathrm{Mg}$ & 0.146 & 0.248 & 0.220 & 0.171 & 0.185 & 0.054 & 0.280 & 0.173 & 0.316 & 0.091 \\
\hline $\mathrm{Na}$ & 0.146 & 0.112 & 0.108 & 0.122 & 0.122 & 0.052 & 0.129 & 0.183 & 0.078 & 0.152 \\
\hline $\mathrm{K}$ & 1.783 & 1.913 & 1.857 & 1.746 & 1.776 & 1.892 & 1.877 & 1.738 & 1.552 & 1.824 \\
\hline
\end{tabular}

celadonitic component (5-6 weight percent $\mathrm{Fe}$ and $c$. one percent Mg; Tab. 3). Minor amounts of $\mathrm{Ti}$ and $\mathrm{Na}$ are also found; fluorine and chlorine do not exceed the detection levels.

Muscovite compositions within pegmatite are uniform (Fig. 6) and generally similar to the muscovite in the host granite. Some of the fine-grained muscovite in the Spruce Pine rocks is very low in $\mathrm{Fe}$, approaching ideal muscovite in composition (Fig. 6). Spruce Pine muscovite plots in or near the field for igneous white mica in granitic rocks (Fig. 6).

\subsection{Biotite}

Biotite occurs in some of the Spruce Pine granodiorites and pegmatites, where it is finer grained and less abundant than the coexisting muscovite. Biotite is found also in parts of the Minpro and Crabtree plutons and in samples from the Sink Hole Mine (Fig. 3). The biotite at Crabtree Creek and Sink Hole forms coarse-grained (10 to $50 \mathrm{~mm}$ ) dendritic crystals termed "crow's foot mica" in the local vernacular. The biotite is black in hand samples and exhibits light to dark-brown pleochroism in thin section.

\subsection{Garnet}

Red euhedral crystals of garnet are a common accessory phase in the Spruce Pine granodiorites and pegmatites. Crystals range from $<1$ to $20 \mathrm{~mm}$ in diameter. Garnet is found in all the pegmatite zones and is often closely as- sociated with grains of muscovite. Most of the garnet is clear and free of inclusions, but a few grains have turbid cores. Flattened crystals of garnet occur between sheets of muscovite. Zones of fine-grained garnet are found in some pegmatites, ranging from irregular patches or lenses to distinct layers. Layers (so called "line rock"), sometimes only one crystal wide, are parallel to both internal and external pegmatite contacts. Garnet forms clear, subhedral to euhedral crystals in the country-rock schists and gneisses.

Garnet in pegmatite and host granodiorite shows the same pattern of compositional variation. The garnet in the granodiorite and pegmatites from the Minpro Pluton and Sink Hole pegmatite is mainly an almandine-spessartine solid solution with only $8-12$ mole percent pyrope + grossular components (Fig. 7, Tab. 4). The garnet in some pegmatite samples shows modest $(8-12$ mole percent spessartine) zoning with the cores slightly higher in $\mathrm{Mn}$ relative to the rim. Garnet is the major Mn-bearing phase in the Spruce Pine granitoid rocks and the zoning reflects removal of $\mathrm{Mn}$ from the magma during crystallization. Samples from a given locality show a limited range of $\mathrm{Fe} / \mathrm{Mn}$ variation (Fig. 7).

Grossular-rich rims occur on granodiorite and pegmatite garnets in samples from Crabtree Creek, Hoot Owl, and McKinney (Fig. 7, Tab. 4). Most of the analyzed grains show at least moderate (10-30 mole percent) enrichment in the grossular component at the rim. Up to 80 mole percent grossular is found in the rims of some garnet crystals. Contacts between Ca-rich rim and the rest of the garnet grain are sharp and are marked by a narrow zone of intermediate composition. 

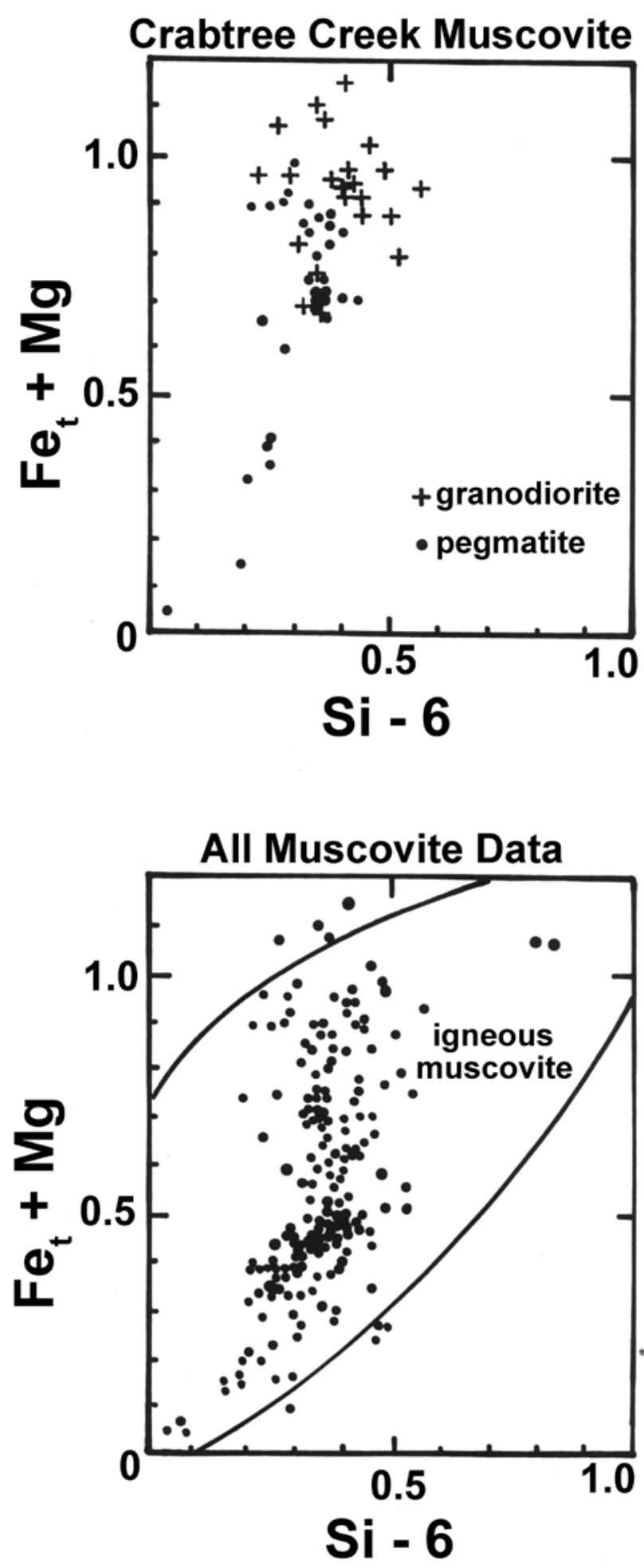

Fig. 6 Composition of muscovite in Crabtree Creek pegmatite and host granodiorite and all of muscovite data (apfu). Field for igneous muscovite is from Zane and Rizzo (1999).

Garnet from the country-rock schist is unzoned and generally lower in $\mathrm{Mn}$ and higher in $\mathrm{Mg}$ than garnets from the granodiorites and pegmatites (Fig. 7). Most of the metamorphic garnet has 17-19 mole percent pyrope + grossular. Spessartine component contents range from 4 to 22 mole percent and the $\mathrm{Fe} / \mathrm{Mn}$ variation overlaps the most Fe-rich garnets from Sink Hole (Fig. 7).

\subsection{Epidote}

Euhedral to anhedral grains of epidote are found in the Spruce Pine granodiorites. The anhedral grains are fine-grained and occur with fine-grained white mica in the matrix mortar structure. Euhedral epidote is fine- to medium-grained and is included in coarse-grained muscovite. Experiments show epidote as a stable phase in granitic magmas at pressures above $0.5 \mathrm{GPa}$ (e.g. Naney 1983). The occurrence of subhedral to euhedral epidote in very coarse-grained muscovite in the Spruce Pine rocks suggests a magmatic origin. The high pressure required to stabilize epidote in granitic magmas is consistent with other indicators of a high-pressure crystallization of the Spruce Pine magmas.

\section{Discussion}

\subsection{Depth of crystallization}

Spruce Pine magma intruded schists and gneisses with little apparent thermal effects. The lack of contact metamorphism suggests that the Spruce Pine intrusions had about the same temperature as the host rocks $(\sim 650$ to $700{ }^{\circ} \mathrm{C}$ ) at the time of intrusion (see earlier discussion in section 2. Geologic background). Most of the intrusive contacts parallel the regional foliation of the metamorphic host rocks and only locally cross-cut the regional fabric.

The generally conformable contacts and the lack of contact metamorphism at Spruce Pine were taken by Buddington (1959) as evidence for emplacement at midcrustal depths (Buddington's "mesozone"). A "deep" emplacement for Spruce Pine magmas was proposed by London (2008) based on a lack of miarolitic cavities and the abundance pegmatitic relative to plutonic rocks. London (2008) cited the gradual transition from granitoid to pegmatite textures, common in the granodiorite-hosted pegmatites at Spruce Pine, as one of the characteristics of deep-seated pegmatites.

The LUF pegmatite, a small dike in the Minpro Pluton, was used as a model for crystallization of Spruce Pine pegmatites (Swanson 2008). Dick Jahns (personal communication 1976) believed that the smaller Spruce Pine pegmatites showed the same pattern of variation (mineral zoning, textural development) as the larger pegmatites. Modal analyses of adjacent K-feldspar megacrysts in the pegmatite were combined with microprobe analyses (Tab. 4) of exsolved and host feldspar chemistries to 


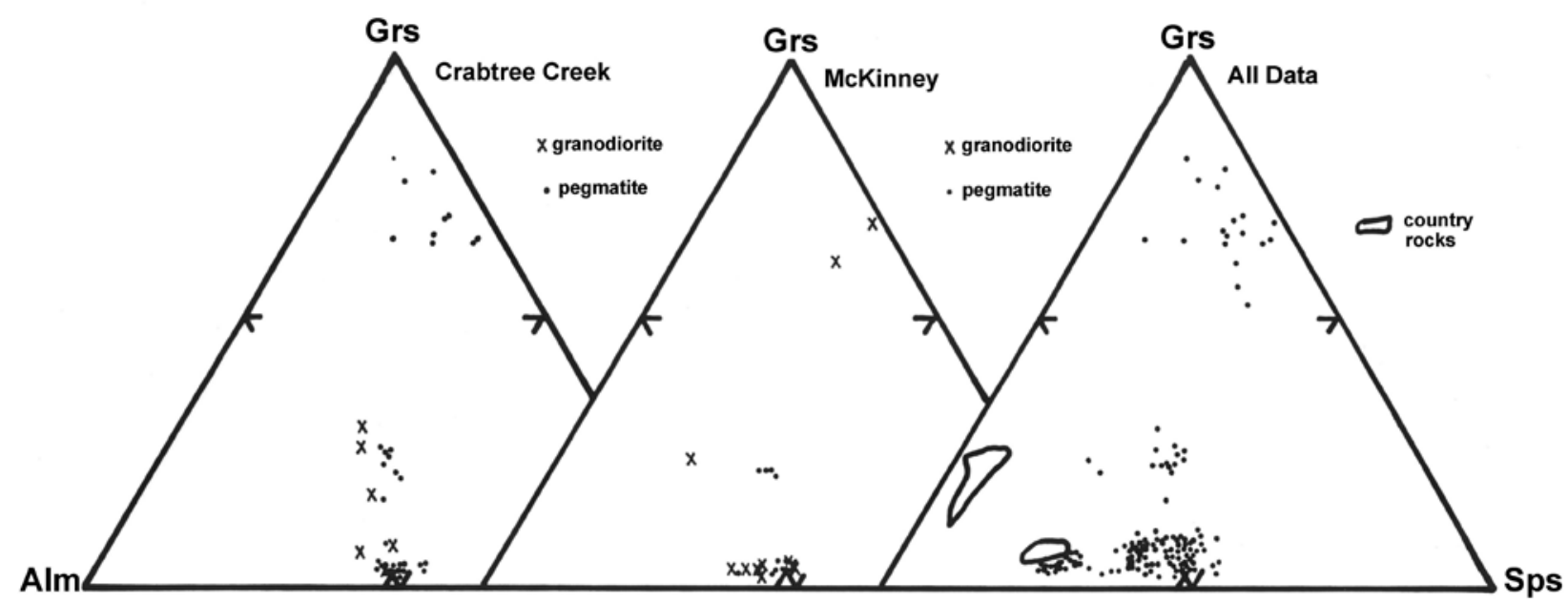

Fig. 7 Composition of garnet (mole percent) in pegmatite and host granodiorite from Crabtree Creek Pluton, McKinney Mine, and all of the garnet data including fields for garnet from country rock schists.

Tab. 4 Composition of zoned garnet in pegmatite and granodiorite from Crabtree Creek (CC), Hoot Owl (HO), and McKinney (MCK) (Fig. 1)

\begin{tabular}{|c|c|c|c|c|c|c|c|c|c|c|}
\hline \multirow{3}{*}{ wt. $\%$ oxide } & \multicolumn{6}{|c|}{ Pegmatite } & \multicolumn{4}{|c|}{ Granodiorite } \\
\hline & \multicolumn{2}{|c|}{$\mathrm{CC} 2-6$} & \multicolumn{2}{|c|}{$\mathrm{HO} 2-2$} & \multicolumn{2}{|c|}{ MCK2-1 } & \multicolumn{2}{|c|}{$\mathrm{CC} 2-1$} & \multicolumn{2}{|c|}{ MCK3-5 } \\
\hline & core & rim & core & rim & core & rim & core & rim & core & $\operatorname{rim}$ \\
\hline $\mathrm{SiO}_{2}$ & 36.29 & 36.77 & 35.93 & 37.60 & 35.47 & 36.36 & 37.16 & 37.76 & 36.18 & 37.98 \\
\hline $\mathrm{TiO}_{2}$ & 0.05 & 0.02 & 0.00 & 0.16 & 0.02 & 0.09 & 0.00 & 0.05 & 0.08 & 0.05 \\
\hline $\mathrm{Al}_{2} \mathrm{O}_{3}$ & 20.80 & 21.01 & 21.25 & 21.57 & 20.54 & 20.73 & 20.61 & 21.09 & 20.30 & 22.13 \\
\hline $\mathrm{FeO}_{\mathrm{t}}$ & 19.84 & 16.17 & 24.93 & 3.20 & 20.58 & 17.09 & 21.43 & 16.76 & 20.01 & 0.85 \\
\hline $\mathrm{MnO}$ & 19.26 & 14.83 & 6.63 & 6.63 & 20.68 & 14.90 & 16.66 & 12.80 & 20.18 & 11.15 \\
\hline $\mathrm{MgO}$ & 0.81 & 0.42 & 15.39 & 0.00 & 0.62 & 0.44 & 1.29 & 0.55 & 0.36 & 0.00 \\
\hline $\mathrm{CaO}$ & 1.53 & 9.51 & 1.32 & 28.61 & 1.32 & 8.99 & 2.83 & 10.61 & 1.48 & 25.88 \\
\hline Total & 98.57 & 98.73 & 99.24 & 97.63 & 99.26 & 98.62 & 99.98 & 99.63 & 98.62 & 98.04 \\
\hline \multicolumn{11}{|c|}{ cations based on 12 oxygens } \\
\hline $\mathrm{Si}$ & 3.000 & 2.989 & 2.967 & 2.962 & 2.948 & 2.974 & 3.018 & 3.022 & 3.008 & 2.978 \\
\hline $\mathrm{Ti}$ & 0.003 & 0.001 & 0.000 & 0.038 & 0.001 & 0.006 & 0.000 & 0.003 & 0.005 & 0.003 \\
\hline $\mathrm{Al}$ & 2.026 & 2.013 & 2.068 & 2.003 & 2.012 & 1.998 & 1.973 & 1.989 & 1.989 & 2.0445 \\
\hline $\mathrm{Fe}$ & 1.372 & 1.100 & 1.721 & 0.211 & 1.431 & 1.169 & 1.456 & 1.122 & 1.391 & 0.056 \\
\hline $\mathrm{Mn}$ & 1.348 & 1.021 & 1.076 & 0.443 & 1.456 & 1.032 & 1.146 & 0.868 & 1.421 & 0.741 \\
\hline $\mathrm{Mg}$ & 0.099 & 0.051 & 0.042 & 0.000 & 0.076 & 0.054 & 0.156 & 0.066 & 0.045 & 0.000 \\
\hline $\mathrm{Ca}$ & 0.135 & 0.828 & 0.117 & 2.415 & 0.117 & 0.788 & 0.247 & 0.910 & 0.132 & 2.174 \\
\hline
\end{tabular}

yield pre-exsolution feldspar compositions (Swanson 2008). Following the method of Whitney and Stormer (1977), they were used to reconstruct the P-T paths. Intersection of the feldspar $\mathrm{P}-\mathrm{T}$ paths with the experimentally determined solidus for the JB5 Spruce Pine bulk composition yielded the pressure $(0.7$ to $1.1 \mathrm{GPa})$ and temperature $\left(\right.$ c. $\left.600{ }^{\circ} \mathrm{C}\right)$ of crystallization (Fig. 8). These estimated crystallization conditions correspond to the amphibolite-grade metamorphism in the country rocks at the time when the Spruce Pine granitoids were intruded. Subsequent development of fine-grained, near end-member muscovite, epidote, and grains of albite in the granitoid rocks represents subsolidus recrystallization during retrograde cooling of the country rocks (Goldberg and Dallmeyer 1997). The grossular rims on some of the Spruce Pine garnets may also represent late-stage recrystallization. Secondary grossular garnet in granite with primary almandine-spessartine garnet was elsewhere attributed to post-magmatic hydrothermal alteration (Leake 1967, 1998). 


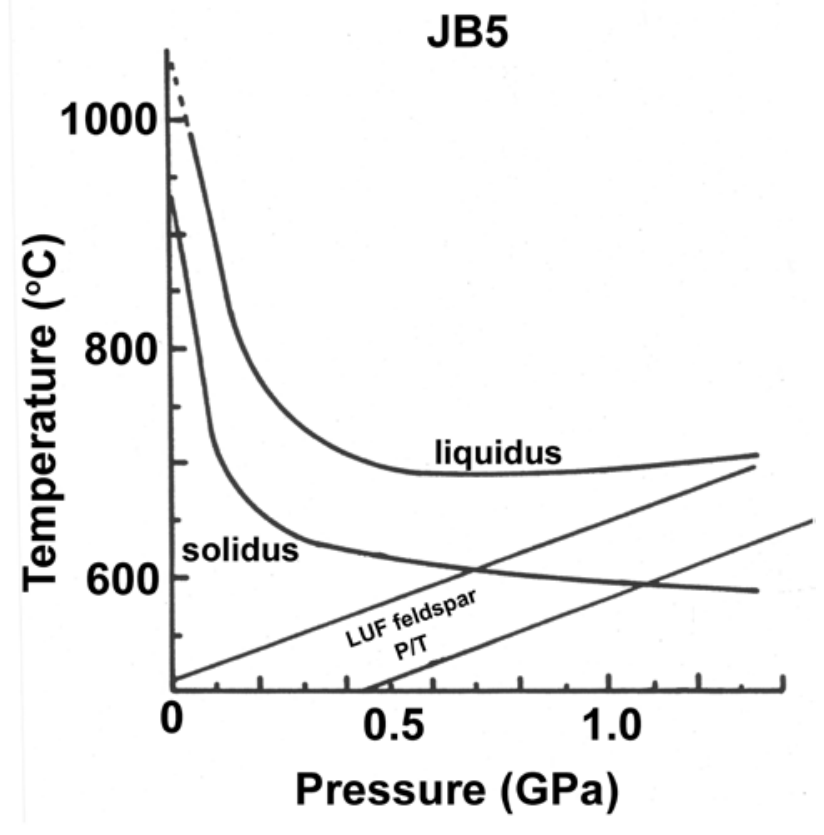

Fig. 8 Melting relations for the Spruce Pine pegmatite composition JB5 taken from Vaughan (1963) and Fenn (1986, and unpublished data). P/T paths for LUF feldspars are based on estimates of feldspar compositions (Tab. 2) recombined to pre-exsolution values (Swanson 2008) following the methods of Whitney and Stormer (1977). See text for details.

\subsection{Mineral compositions}

Mineral compositions in the pegmatites and associated granodiorites show the same pattern of variation. There are some regional differences in mineral composition, but the overall similarity of minerals in individual granitoid and associated pegmatitic rocks suggests little fractionation between granitoid and pegmatitic magmas. This view is supported by the gradual transition from granitoid to pegmatitic texture observed in the pegmatites hosted by granodiorite (Fig. 4). There is some mineralogical evidence of some moderate fractionation as evidenced by the presence of beryl and tourmaline in a few of the pegmatites (e.g. Tappen and Smith 2003) or even extreme fractionation in the case of one pegmatite that contains spodumene, pollucite, amazonite, and fluorite (Wise and Brown 2009). However, well over 95 percent of the pegmatites are simple garnet-muscovite pegmatites, lacking in more exotic minerals (Lesure 1968). The lack of evidence for fractionation begs the question, why are pegmatitic rocks so abundant in the Spruce Pine granitoids?

\subsection{Textural development}

Confusion about the nature (pegmatite or granitoid) of Spruce Pine granodiorites comes from the coarse to very coarse-grained crystal sizes present in both rock types and the range of grain sizes. K-feldspar megacrysts over one meter in diameter occur in both the granodiorite and the pegmatite. Plagioclase crystals larger than a meter also occur in the granodiorite. The distinction between the pegmatite and the granodiorite textures is based on the occurrence of very coarse grained quartz and muscovite in the pegmatite, while these phases are somewhat finer grained in the granodiorite. Large feldspar crystals in the granodiorite are surrounded by a matrix of fine to coarse-grained K-feldspar, plagioclase, muscovite, and garnet.

Large crystals of plagioclase and K-feldspar in granodiorite were predicted by Swanson (1977) based on the results of experiments on crystallization kinetics. Plagioclase is the liquidus phase in both the Spruce Pine composition, JB5, and in the synthetic granodiorite bulk composition, R5, studied by Swanson. K-feldspar crystallized following quartz (and plagioclase) in JB5 and R5 (Swanson 1977; Fenn 1986). Crystallization kinetics of plagioclase and $\mathrm{K}$-feldspar in the R5 bulk composition is summarized in Fig. 9. The coincidence of high growth rates and relatively low number of nuclei results in the initial growth of a few large crystals of plagioclase. Once temperatures cool to stabilize K-feldspar, the pattern of high growth rates and low numbers of nuclei again coincide and results in coarse-grained $\mathrm{K}$-feldspar in the granodiorite.

London (2008) attributed the development of pegmatitic texture to crystallization kinetics involving delayed nucleation (undercooling) in magma related to the abundance of hydrous components in the magma. Abundant skeletal crystals reflecting crystallization from

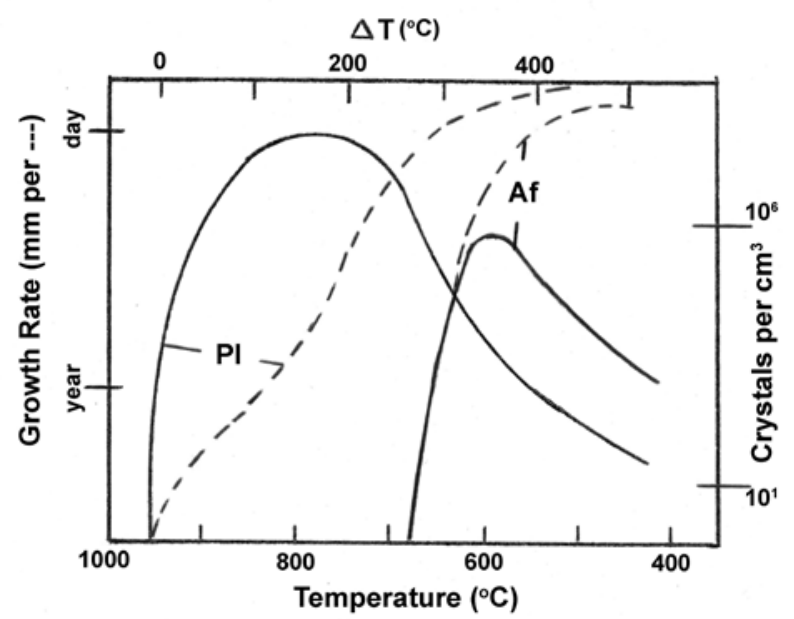

Fig. 9 Crystallization kinetics for plagioclase (Pl) and alkali feldspar (Af) in a synthetic granodiorite composition (R5) modified from Swanson (1977). Growth rate (solid lines) and nucleation density (dashed lines) are shown as a function of temperature. 

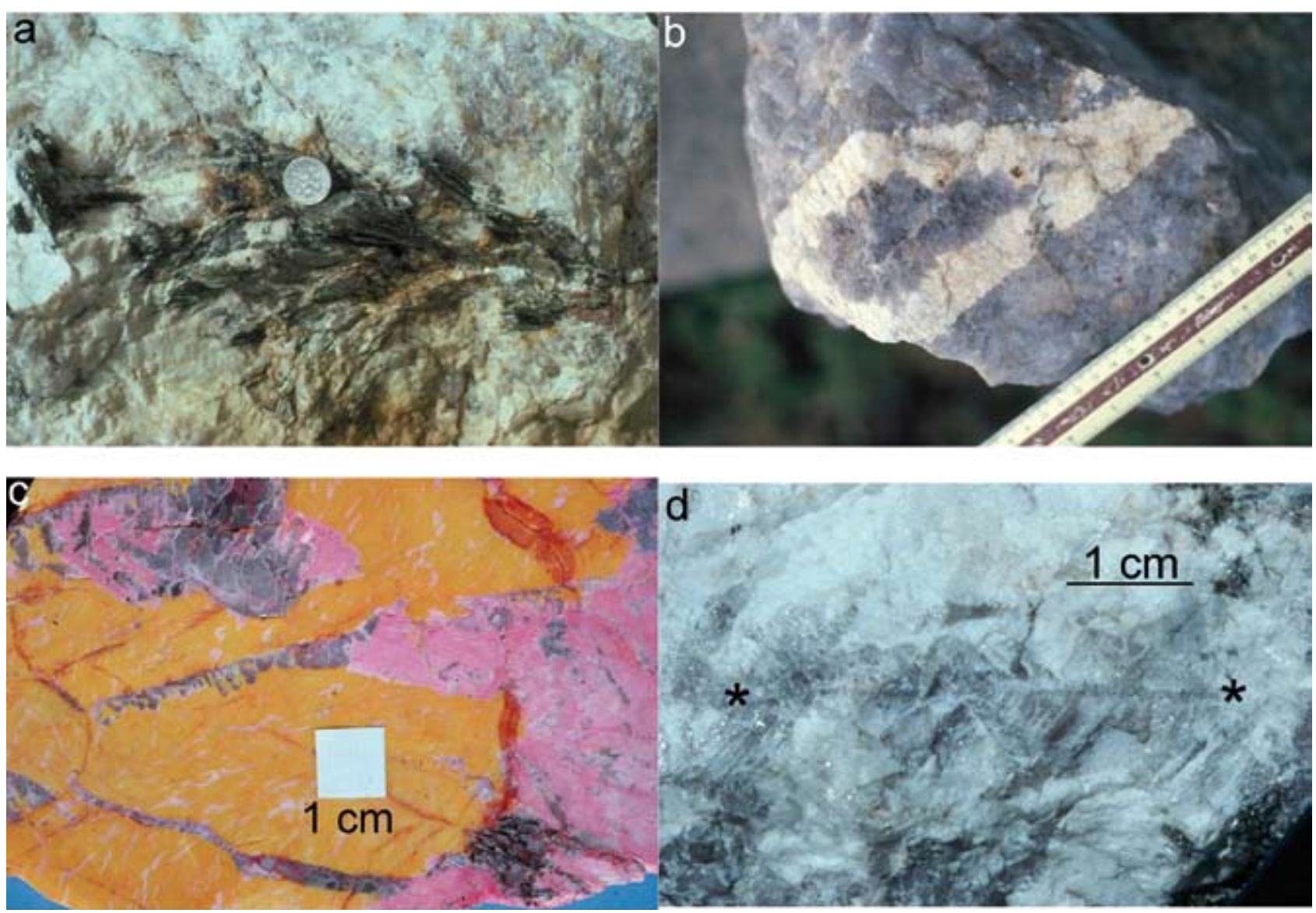

Fig. 10 Skeletal crystals in Spruce Pine pegmatites. a - Plumose muscovite in McKinney pegmatite, coin is about $1 \mathrm{~cm}$ in diameter. b - Skeletal K-feldspar crystal in quartz from a McKinney pegmatite core. c - Stained slab of K-feldspar (orange) and plagioclase (pink) showing skeletal crystals of quartz from McKinney pegmatite. White square is $1 \mathrm{~cm}$ on a side. $\mathbf{d}$-Skeletal crystal of quartz (below Qtz) in feldspar from McKinney pegmatite.

an undercooled magma are found in the Spruce Pine pegmatites (Fig. 10). Experiments with the Spruce Pine bulk composition (Fenn 1986; Swanson and Fenn 1986) illustrate the development of skeletal crystals of quartz and K-feldspar from Spruce Pine melts. The large size of the skeletal crystals in the Spruce Pine pegmatites is probably related to the high pressure of crystallization. High pressure favors the increased solubility of hydrous components in the Spruce Pine magmas (Burnham 1967; Burnham and Nekvasil 1986). Nucleation of feldspar and quartz is known to be delayed in hydrous melts (e.g. Fenn 1977; Swanson 1977). Local enrichment of hydrous components in crystallizing Spruce Pine magma may have resulted in pockets of magma saturated with a hydrous vapor phase. Delayed nucleation in this vapor-saturated magma can produce pegmatitic textures complete with skeletal crystals. Crystallization of vapor-saturated magma in situ resulted in a gradational transition from textures typical of the granodiorite to those of pegmatites. Migration of vapor-saturated magma produced the dikes of pegmatite with sharp contacts against the granodiorite.
Local accumulation of vapor-saturated magma without any open-space miarolitic cavities is related to the high pressure of the system.

\section{Conclusions}

Spruce Pine magmas crystallized granodiorites and pegmatites at high pressure, near the end of the peak regional metamorphic event. Mineral assemblages and compositions of pegmatites mimic those of Spruce Pine granodiorites: plagioclase, quartz, K-feldspar, accessory muscovite and garnet, and traces of epidote. A small percentage of Spruce Pine pegmatites contain beryl and/or tourmaline and rarely spodumene and pollucite, reflecting extreme fractionation of the Spruce Pine magmas. Simple zoning with a core of quartz-K-feldspar occurs in about half of the Spruce Pine pegmatites.

Spruce Pine pegmatites are muscovite-class pegmatites (Černý 1991) and crystallized at high pressure from anatectic melts. Local accumulations (fractionation) of 
hydrous components during crystallization produced the pegmatitic textures. The fractionation of non-hydrous components was limited and the magmas crystallized granodiorite with the same mineral assemblage as the pegmatites. Large crystals of plagioclase and K-feldspar in granodiorites formed in response to the crystallization kinetics in these systems.

Cooling of these deep-seated intrusions (pegmatites and granodiorites) produced a range of cooling ages, post-magmatic deformation, and recrystallization (including secondary minerals).

Acknowledgements. The late Dick Jahns was a friend of Spruce Pine pegmatites and his guidance in the early stages of this study is acknowledged. Alex Glover was a valuable guide to many of the Spruce Pine pegmatites during later stages of this study. Chris Fleisher aided with the electron microprobe analyses at the University of Georgia and W. C. Luth did feldspar analyses of LUF samples at Sandia National Laboratory. The Geology Department of the University of Georgia and the Geology Department at Appalachian State University supported this study. Some of the data in this study came from Veal's Masters Thesis at the University of Georgia. Veal was supported in this work by the Wheeler-Watts and Allard funds through the Department of Geology at the University of Georgia, which are gratefully acknowledged. Mona Sirbescu and Rainer Thomas provided useful reviews and the paper was improved by their comments.

\section{References}

Aввотt RN JR, RaYmond LA (1984) The Ashe metamorphic suite, northwest North Carolina: metamorphism and observations on geologic history. Amer J Sci 284: 350-375

Adams MG, Trupe CH (1997) Conditions and timing of metamorphism in the Blue Ridge Thrust Complex, northwestern North Carolina and eastern Tennessee. In: Stewart KG, Adams MG, Trupe CH (eds) Paleozoic Structure, Metamorphism, and the Tectonics of the Blue Ridge of Western North Carolina. Field Trip Guidebook, Carolina Geological Society, Durham, NC, pp 33-47

Adams MG, Stewart KG, Trupe CH, Willard RA (1995) Tectonic significance of high-pressure metamorphic rocks and dextral strike-slip faulting along the Taconic suture. In: Hibbard JP, van Stall CR, Cawood PA (eds) Current Perspectives in the Appalachian-Caledonian Orogen. Geological Association of Canada Special Papers 41: 21-42

Aldrich LT, Wetherill GW, Davis GL, Tilton GR (1958) Radioactive ages of micas from granitic rocks by $\mathrm{Rb}-$ $\mathrm{Sr}$ and $\mathrm{K}-\mathrm{Ar}$ methods. Trans Amer Geophys Union 39: 1124-1134
BRobst DA (1962) Geology of the Spruce Pine District, Avery, Mitchell and Yancey counties, North Carolina. US Geol Surv Bull 1122-A: 1-62

BudDington AF (1959) Granite emplacement with special reference to North America. Geol Soc Am Bull 70: 671-747

Burnham CW (1967) Hydrothermal fluids at the magmatic stage. In: BARNES H (ed) Geochemistry of Hydrothermal Ore Deposits. Holt, Rinehart and Winston, New York, pp 34-76

BURNHAM CW, JAHNS RH (1958) The solubility of water in granitic magmas. 1. Experimental studies of pegmatite genesis. Geol Soc Am Bull 69: 1544-1545

BURNHAM CW, JAHNS RH (1962) A method for the determining the solubility of water in silicate melts. Amer J Sci 260: 721-745

Burnham CW, NeKvasil H (1986) Equilibrium properties of granite pegmatite magmas. Amer Miner 71: 239-263

ButLer JR (1973) Paleozoic deformation and metamorphism in part of the Blue Ridge thrust sheet, North Carolina. Amer J Sci 273-A: 72-88

ButLer JR (1991) Metamorphism. In: HoRTon JW, ZulLa VA (eds) The Geology of Carolina: Geological Society Fiftieth Anniversary Volume. University of Tennessee Press and Carolina Geological Society, Knoxville, pp 127-141

Cameron EN, Jahns RH, McNair AH, Page LR (1949) Internal structure of granitic pegmatites. Econ Geol Mon 2: 1-115.

ČERNÝ P (1991) Rare-element granite pegmatites. I. Anatomy and internal evolution of pegmatite deposits. Geosci Can 18: 49-67

FenN PM (1977) The nucleation and growth of alkali feldspars from hydrous melts. Canad Mineral 15: 135-161

FENN PM (1986) On the origin of graphic granite. Amer Miner 71: 325-330

Glover A (2006) The Spruce Pine Mining District - a brief review of the history, geology and modern uses of minerals mined in the Spruce Pine Mining District, Mitchell, Avery and Yancey counties, North Carolina. In: REID JC (ed) Proceedings of the $42^{\text {nd }}$ Forum on the Geology of Industrial Minerals. North Carolina Geological Survey Information Circular 34: pp 269-271.

Goldberg SA, Dallmeyer RD (1997) Chronology of Paleozoic metamorphism and deformation in the Blue Ridge Thrust Complex, North Carolina and Tennessee. Amer J Sci 297: 488-526

Hatcher RD JR, Merschat AJ, Thigpen JR (2005) Blue Ridge primer. In: HATCHER RD JR, MERSCHAT, AL (eds) Blue Ridge Geologic Traverse East of the Great Smoky Mountains National Park, Western North Carolina. 2005 Field Trip Guidebook, Carolina Geological Society, Durham, NC, pp 1-24

Hatcher RD Jr, Bream, BR, Merschat AJ (2007) Tectonic map of the southern and central Appalachians: a tale of 
three orogens and a complete Wilson cycle. In: HATCHER RD JR, Carlson MP, McBride, MP, Martínez Catalán JR (eds) 4-D Framework of Continental Crust. Geological Society of America Memoirs 200: pp 595-632

JAHNS RH (1955) The study of pegmatites. Econ Geol 50: 1025-1130

JAHNS RH, BuRnham CW (1957) Preliminary results from experimental melting and crystallization of Harding, New Mexico, pegmatite. Geol Soc Am Bull 68: 1751-1752

JaHNS RH, BuRnhAM CW (1958) Melting and crystallization of granite and pegmatite 2. Experimental studies of pegmatite genesis. Geol Soc Am Bull 69:1592-1593

JAHNS RH, BURNHAM CW (1969) Experimental studies of pegmatite genesis: I. A model for the derivation and crystallization of granitic pegmatites. Econ Geol 64: 843-864

Johnson BS, Miller B, Stewart K (2001) The nature and timing of Acadian deformation in the southern Appalachian Blue Ridge constrained by the Spruce Pine Plutonic Suite, western North Carolina. Geol Soc Amer Abs Prog 33: A30

KisH SA (1983) A geochronological study of deformation and metamorphism in the Blue Ridge and Piedmont of the Carolinas. Unpublished Ph.D. thesis, University of North Carolina, Chapel Hill, pp 1-220

KisH SA (1989) Paleozoic thermal history of the Blue Ridge in southwestern North Carolina - constraints based on mineral cooling ages and the ages of intrusive rocks. Geol Soc Amer Abs Prog 21: 45

LEAKE BE (1967) Zoned garnets from the Galway Granite and its aplites. Earth Planet Sci Let 3: 311-316

LEAKE BE (1998) Widespread secondary Ca garnet and other Ca silicates in the Galway Granite and its satellite plutons caused by fluid movements, western Ireland. Mineral Mag 62: 381-386

Lesure FG (1968) Mica deposits of the Blue Ridge in North Carolina. US Geological Survey Professional Papers 557: pp 1-124

London D (2008) Pegmatites. Mineralogical Association of Canada, Québec, pp 1-347

Margolin PR (2000) The Sink Hole at Bandana: a historic Blue Ridge mica mine reveals its past. NC Arch 49: 43-58

Maurice CS (1940) The pegmatites of the Spruce Pine District, North Carolina. Econ Geol 35: 49-78, 158-187

Miller CF, Hatcher RD JR, Ayers JC, Coath CD, HarRISON, TM (2000) Age and zircon inheritance of eastern Blue Ridge plutons, southwestern North Carolina and northeastern Georgia, with implications for margin history and evolution of the southern Appalachian orogen. Amer J Sci 300: 142-172

NANey MT (1983) Phase equilibria of ferromagnesian rock-forming silicates in granitic systems. Amer J Sci 283: 993-1033
Olson JC (1944) Economic geology of the Spruce Pine pegmatite district, North Carolina. NC Min Res Div Bull 43, pp 1-67

PARKER JM III (1952) Geology and structure of part of the Spruce Pine pegmatite district, North Carolina. NC Min Res Div Bull 65, pp 1-26

RaYmond LA (1995) The Study of Igneous, Sedimentary, and Metamorphic Rocks. W. C. Brown, Dubuque, pp $1-742$

Shannon JR, Walker BM, Carten RB, Geraghty EP (1982) Unidirectional solidification textures and their significance in determining relative ages of intrusions at the Henderson Mine, Colorado. Geology 10: 293-297

Stewart KG, Adams MG, Trupe CH (1997) Paleozoic structural evolution of the Blue Ridge Thrust Complex, western North Carolina. In: Stewart KG, Adams MG, TRupe CH (eds) Paleozoic Structure, Metamorphism, and Tectonics of the Blue Ridge of Western North Carolina. Carolina Geological Society Guide Book, Raleigh NC, pp 21-31

Swanson SE (1977) Relation of nucleation and crystal growth rate to the development of granitic textures. Amer Miner 62: 966-978

Swanson SE (1978a) Morphology of quartz and alkali feldspar from the McKinney Mine, Spruce Pine District, North Carolina. EOS Trans Amer Geophys Union 59: 396

Swanson SE (1978b) Snowflake-like quartz, McKinney Mine, North Carolina - evidence for rapid crystallization. Geol Soc Amer Abs Prog 10: 199

Swanson SE (2008) Petrogenesis of a small Spruce Pine pegmatite: a model for the petrogenesis of Spruce Pine granitoids, In: ReID JC (ed) Carolina Geological Society Guidebook, Raleigh NC, pp 1-29

Swanson SE, Fenn PM (1986) Quartz crystallization in igneous rocks. Amer Miner 71: 331-342

Swanson SE, Veal WB (2006) Texture: it is what makes Spruce Pine granites special. In: ReID JC (ed) Proceedings of the $42^{\text {nd }}$ Forum on the Geology of Industrial Minerals. North Carolina Geological Survey Information Circular 34, pp 537

Townsend, RF, Sharp RV (eds) (2004) Hero, Hawk and Open Hand. The Art Institute of Chicago, pp 1-287

TAPPEN CM (1998) Beryl and Tourmaline Mineralization of the Crabtree Pegmatite, Spruce Pine District, North Carolina. Unpublished MSci. thesis, University of North Carolina, Wilmington, NC, pp 1-115

Tappen CM, Smith MS (2003) The Crabtree Pegmatite, Spruce Pine District, North Carolina: mineralization and host rock relationships. Southeast Geol 41: 201-223

Vaughan DEW (1963) The Crystallization Ranges of the Spruce Pine and Harding Pegmatites. Unpublished MSci. thesis, Penn State University, University Park, PA, pp 1-66 
Veal WB (2004) Mineralogy of the Peraluminous Spruce Pine Plutonic Suite, Mitchell, Avery, and Yancey Counties, North Carolina. Unpublished MSci. thesis, University of Georgia, Athens, GA, pp 1-213.

Warner RD, Poterala S, Fleisher C (2008) A note on uranium minerals from the Spruce Pine area, North Carolina. In: ReID JC (ed) Carolina Geological Society 2008 Guidebook, Raleigh NC, pp 29-52

Whitney JA, Stormer JC III (1977) Two-feldspar geothermometry, geobarometry in mesozonal granitic intrusions: three examples from the Piedmont of Georgia. Contrib Mineral Petrol 63: 51-64

Wise MA, BRown CD (2009) Extreme rare-earth element enrichment in a muscovite-rare-element class granitic pegmatite: a case study of the spodumene-amazonite McHone pegmatite, Spruce Pine, North Carolina. Southeast Geol 46: 155-172

Wood PA (1995) Petrogenesis of the Spruce Pine Pegmatites, North Carolina. Unpublished MSci. Thesis, Virginia Polytechnic Institute and State University, Blacksburg, pp 1-99

WriGHT TL (1968) X-ray and optical study of alkali feldspar: II. An X-ray method for determining the composition and structural state from measurement of $2 \theta$ values for three reflections. Amer Miner 53: 88-104

Zane A, Rizzo G (1999) The compositional space of muscovite in granitic rocks. Canad Mineral 37: 1229-1238 